\title{
ANÁLISE DA ESTABILIDADE DAS FALÉSIAS DE TIBAU DO SUL POR MÉTODOS DE EQUILÍBRIO-LIMITE
}

\author{
G.H.S.Pacheco ${ }^{1}$, O. de Freitas Neto ${ }^{2}$, R.N.F. Severo ${ }^{3}$ \\ ${ }^{1}$ Aluno do curso de Tecnologia em Produção da Construção Civil do Centro Federal de \\ Educação Tecnológica do Rio Grande do Norte (CEFETRN) \\ pagio_gio@yahoo.com.br \\ ${ }^{2}$ Aluno do Curso de Engenharia Civil da Universidade Federal do Rio Grande do Norte \\ (UFRN) \\ osvaldocivil@yahoo.com.br \\ ${ }^{3}$ Professor do Curso de Tecnologia em Produção da Construção Civil do CEFETRN \\ ricardoflores@cefetrn.br
}

Artigo apresentado no III Congresso de Iniciação Científica do CEFETRN (2005)

\begin{abstract}
RESUMO
Um dos principais problemas da zona costeira é o avanço da linha de costa. Para analisar a estabilidade dos taludes que compõem essas linhas de costa no município de Tibau do Sul, $\mathrm{RN}$, foi realizado este trabalho. Ele consiste em realizar simulações a respeito da estabilidade dos taludes através do cálculo do Fator de Segurança (valor adimensional que exprime a estabilidade do talude na sua situação mais crítica), utilizando métodos de equilíbrio limite pelo software SLOPE/W da GEO-SLOPE Versão Estudante. Foram realizadas simulações variando-se o grau de saturação do solo das falésias, a fim de se conhecer a influência da saturação na instabilização dos taludes, assim como obter o limite de saturação que as falésias suportam sem que haja ruptura. Também se obteve a provável superfície de ruptura em caso de instabilização. Pelos resultados pôde-se constatar que a saturação total do solo pode reduzir em até quatro vezes o valor do Fator de Segurança, acarretando deslizamentos de grande intensidade nas falésias em que não está presente a camada cimentada com óxido de ferro.
\end{abstract}

PALAVRAS-CHAVE: Estabilidade de Taludes, Falésias, Tibau do Sul-RN, Coesão, Ângulo de Atrito, Superfície de Ruptura, Fator de Segurança, SLOPE/W.

\section{THE STABILITY ANALISIS OF CLIFFS IN TIBAL DO SUL USING THE LIMITED BALANCE METHOD}

\begin{abstract}
One of the main problems of the coastal zone is the advance of the shoreline. To analyze the stability of the slopes that compose these shorelines in the city of Tibau do Sul, RN, was carried through this work. It consists of to carry through simulation regarding stability of slopes through calculation of Factor of Security (undimension value that it states the stability of the slope in its more critical situation), using limited balance methods for software SLOPE/W of the Geo-slope Version Student. Simulations had been carried through varying the degree of saturation of the ground of the slopes, in order to know the influence of the saturation in the instability of slopes, as well as getting the saturation limit that the slopes support without that it has rupture. Also the probable surface of rupture in instability case was gotten. For the results it could be evidenced that the total saturation of
\end{abstract}


the ground can reduce for twenty five percent the value of the Factor of Security, causing landslides of great intensity in slopes where the layer cemented with iron oxide is not present.

KEYWORDS: Slope stability, Slope, Tibau do Sul-RN, Cohesion, Angle of Attrition, Surface of Rupture, Factor of Security, SLOPE/W. 


\section{ANÁLISE DA ESTABILIDADE DAS FALÉSIAS DE TIBAU DO SUL POR MÉTODOS DE EQUILÍBRIO-LIMITE}

\section{INTRODUÇÃO}

A dinamicidade da zona costeira desperta uma atenção especial de pesquisadores para essa região. No litoral do Rio Grande do Norte, mais especificamente nas falésias presentes em toda linha de costa do município de Tibau do Sul, diversas pesquisas vem sendo realizadas. Essa área vem sendo ocupada com grande velocidade a partir dos anos 80, provocando grande adensamento populacional, bem como a construção de novos empreendimentos turísticos próximos à borda das falésias.

A erosão costeira, provocada pela ação das ondas do mar, e as precipitações pluviométricas acarretam deslizamentos de terra que têm causado muitos prejuízos para a região. Os agentes modificadores do relevo, como chuvas e ondas, recebem a contribuição dos ventos e da ação antrópica, principalmente o desmatamento, para alterar o perfil da linha de costa. Portanto, fazem-se necessárias pesquisas para prever possíveis movimentos de terra nas falésias.

A pesquisa consistiu em realizar análises através do software canadense SLOPE-W da GEO-SLOPE Versão Estudante, visando conhecer o Fator de Segurança e também a provável superfície de ruptura em caso de instabilização, ou seja, quando o Fator de segurança é menor do que 1,0 .

Utilizaram-se diferentes níveis de saturação em cada situação formulada. Fez-se uso dos parâmetros do solo de quatro amostras retiradas da região onde se encontram as falésias. O software utiliza métodos baseados no equilíbrio-limite, para a determinação do Fator de Segurança. No presente trabalho utilizou-se os métodos de Fellenius, Bishop Simplificado, Janbu Simplificado e Morgenstern-Price.

A pesquisa identificou as situações em que o nível de saturação do solo das falésias provoca sua instabilização. E ainda mostrou como a camada cimentada existente em alguns trechos das falésias contribui para a sua estabilização.

\section{OBJETIVO}

Analisar a estabilidade das falésias que compõem o litoral de Tibau do Sul através dos Métodos de Equilíbrio Limite.

\section{DESCRIÇÃO DA ÁREA ESTUDADA}

A área de estudo está localizada na zona costeira leste do Rio Grande do Norte (figura 1), aproximadamente $60 \mathrm{~km}$ ao sul de Natal. Em termos geológicos a área é constituída por sedimentos terciários da Formação Barreiras, os quais consistem de camadas intercaladas de arenitos argilosos, argilitos e conglomerados. Em alguns locais aparecem camadas de elevada consistência devido à cimentação com óxido de ferro. É verificada também a presença de sedimentos arenosos eólicos (dunas) recobrindo 
parcialmente os Tabuleiros constituídos pela Formação Barreiras, e junto à linha de costa, estão presentes as praias arenosas. A borda dos Tabuleiros Litorâneos são as falésias com alturas iguais ou inferiores a 40 metros.

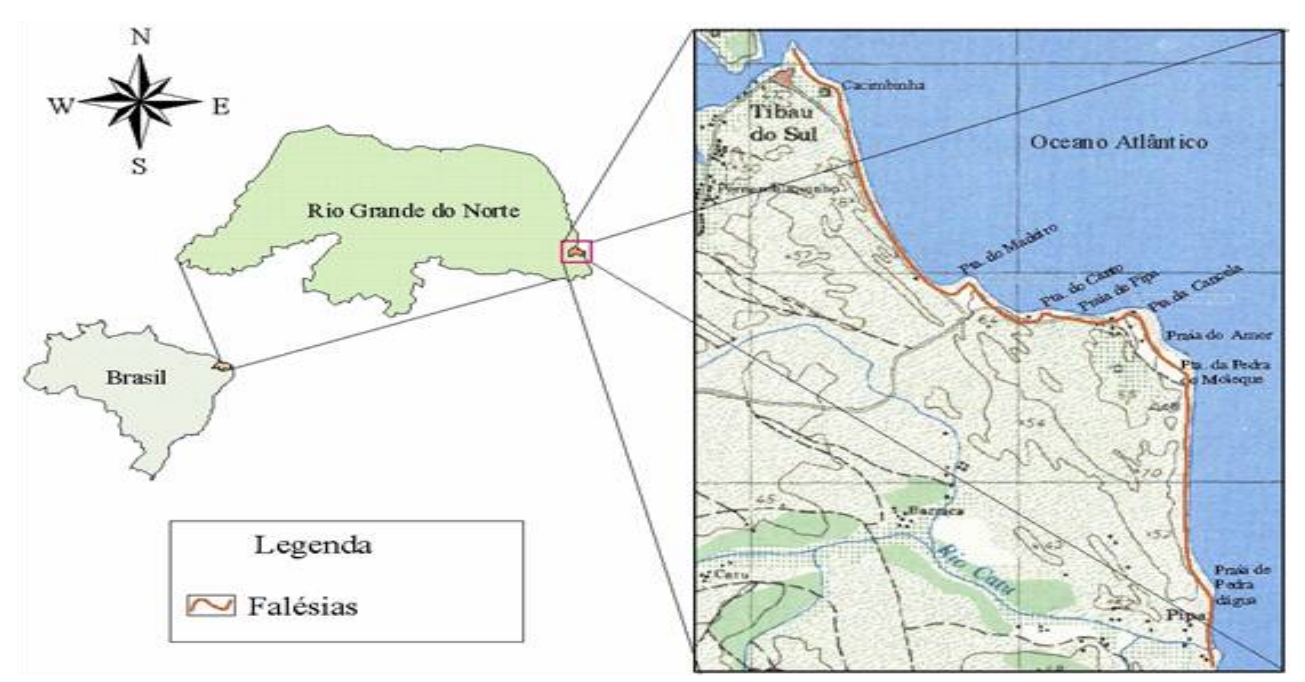

Figura 1 - Localização geográfica da região de Tibau do Sul

\section{METODOLOGIA}

Foram realizados estudos em obras bibliográficas a fim de se conhecer os possíveis movimentos de massa que ocorrem nos taludes e prevenir tais movimentos. Com esses estudos e a obtenção de parâmetros de resistência dos solos prosseguiu-se a formulações de análises no software computacional GEO-SLOPE.

\subsection{CONSIDERAÇÕES SOBRE MOVIMENTO DE MASSAS EM ENCOSTAS}

\subsubsection{Talude}

Talude ou encosta é toda superfície natural inclinada que une duas ou mais superfícies caracterizadas por diferentes energias potenciais. Sob o aspecto genético, os taludes podem ser naturais ou artificiais. Os naturais são maciços terrosos, rochosos ou mistos de solos e rochas, originados por agentes naturais, mesmo que tenham sofrido alguma alteração antrópica, tais como desmatamentos, cortes e a introdução de cargas. Já os taludes artificiais, são declives de aterros a partir de vários materiais em estrutura conhecida e exibem uma homogeneidade mais acentuada que os naturais, que só têm sua estrutura particular conhecida através de criterioso processo de prospecção (GUIDICINI e NIEBLE, 1984).

\subsubsection{Movimentos de massa nas encostas}

Segundo Santos Jr. e Nóbrega (2000), ao estudar uma falésia, devemos levar em consideração que quaisquer que sejam os objetivos do estudo é preciso identificar e classificar os vários tipos de movimento de massa, seus aspectos geológicos, a velocidade do movimento e as causa da instabilização, bem como classificar e descrever o material 
envolvido no movimento, juntamente com a quantificação das propriedades relevantes ao objetivo do estudo.

Os movimentos de massas consistem em movimentos coletivos de solo, rocha ou mistura de ambos, que resultam de processos de ruptura ou de desestabilização das encostas. Os movimentos de massas podem ser classificados em função da geometria da superfície de ruptura, da cinemática do movimento, da velocidade e do tipo de material envolvido.

As causa do movimento enumeradas por Terzaghi (1950), são colocadas em três níveis: causas externas (acréscimo de tensões cisalhantes), internas (redução da resistência ao cisalhamento) e intermediárias (liquefação espontânea, erosão interna e rebaixamento do nível d'água). Vale salientar que os aumentos da altura, de inclinação, bem como a ação da água, são as causas mais comuns.

De maneira geral, os movimentos podem ser classificados como: escorregamentos ou deslizamento (Figura 2), quedas (Figura 3), tombamentos (Figura 3), escoamentos e movimento complexos (SILVA, 2003).

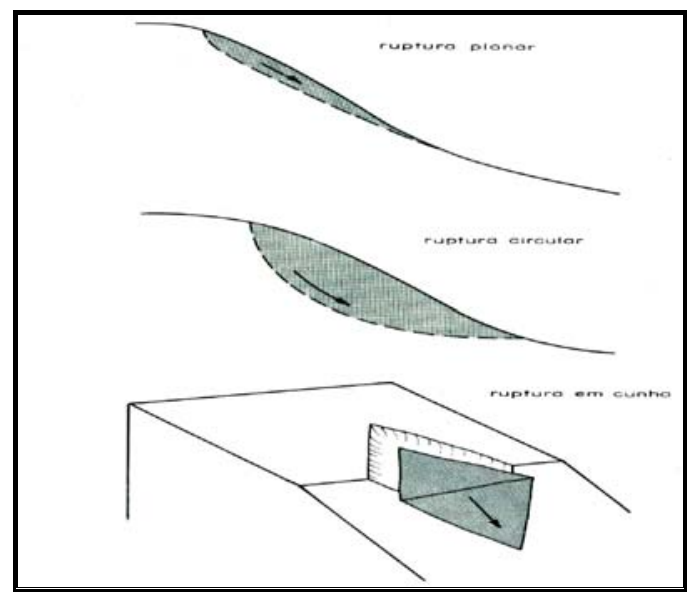

Figura 2 - Mecanismo do Deslizamento (SANTOS Jr. e NÓBREGA, 2000).

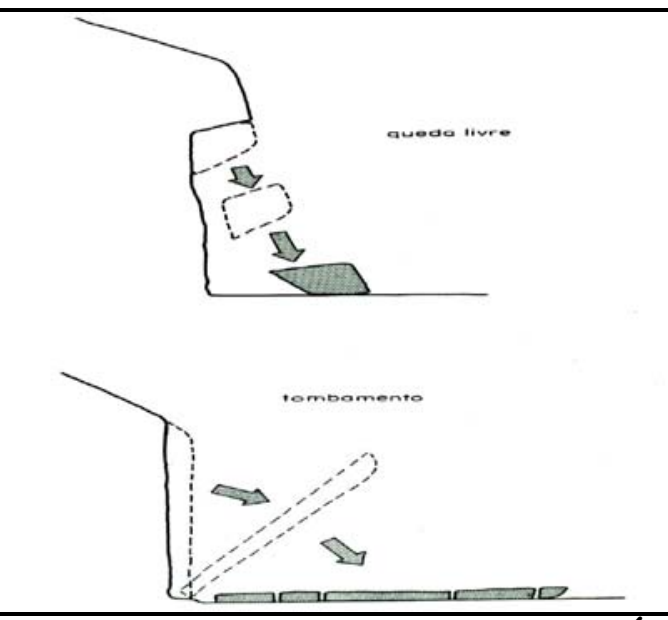

Figura 3 - Mecanismo da Queda (SANTOS Jr. e NÓBREGA, 2000). 


\subsubsection{Movimentos de massa e processos erosivos em Tibau do Sul}

Na área estudada, registrou-se a existência de movimentos de massa classificados predominantemente como complexos, por consistirem de mais de um tipo de movimento (quedas de blocos, tombamentos e deslizamentos). Esses fenômenos são mais freqüentemente verificados em taludes com a presença de fendas de tração e incisões basais, sem vegetação, com grande inclinação $\left(80^{\circ}\right.$ a $\left.90^{\circ}\right)$ e grande altura (cerca de $40 \mathrm{~m}$ ). No caso dos deslizamentos, observa-se a ocorrência dos tipos planares e circulares.

A ausência de vegetação em alguns trechos da área estudada deixa as falésias vulneráveis à ocorrência de movimentos de massa. A cobertura vegetal constrói ao longo do tempo um sistema radicular que estrutura as camadas superficiais do solo.

Em períodos chuvosos (entre abril e julho), é comum o desencadeamento de deslizamentos e tombamentos nos taludes desprovidos de vegetação. Tal situação é mais grave quando essa ausência é verificada na face da encosta.

\subsection{ANÁLISE DA ESTABILIDADE DAS FALÉSIAS}

\subsubsection{Tipos de Solos}

Para realizarem-se essas análises, constatou-se em visitas in situ, realizadas por Severo, 2005, que o solo que forma as falésias se divide em duas camadas diferentes, os solos da parte superior e os solos da parte inferior. Baseado na cor da argila era claramente possível identificar dois tipos principais de materiais. A parte superior das falésias é composta de argila arenosa vermelha com a presença de óxido de ferro. Argila branca era notada com mais nódulos rígidos vermelhos na parte mais baixa. Verificou-se, em alguns casos, a presença de camada cimentada na interface dessas camadas, com aproximadamente 2 metros de espessura.

Severo (2005) coletou três amostras indeformadas de solos dos topos e uma da base das falésias. As amostras dos solos dos topos foram coletadas em três locais distintos: na região de Piau, chamado na pesquisa de Solo Topo Piau; nas proximidades da BR 101, chamado de Solo Topo BR 101; e na parte central das falésias, chamado de Solo Topo Falésia. As amostras de solos da base foram provenientes das falésias. Os solos das bases serão tratados nesta pesquisa por Solo Base.

Este realizou ensaios de cisalhamento direto com as amostras no estado inundado e na umidade natural, adquirindo os parâmetros dos solos necessários para os cálculos de estabilidade. Para a camada cimentada os parâmetros foram estimados devido à dificuldade na obtenção de amostras indeformadas. Os parâmetros dos solos estão apresentados na Tabela 1. 
Tabela 1 - Parâmetros de Resistência do Solo

\begin{tabular}{|c|c|c|c|}
\hline Solo & Parâmetros & Umidade Natural & Inundado \\
\hline \multirow{3}{*}{$\begin{array}{l}\text { Solo Topo- } \\
\text { Falésia }\end{array}$} & $\phi\left(^{\circ}\right)$ & 27,7 & 27,5 \\
\hline & $\mathrm{c}(\mathrm{kPa})$ & 233,0 & 50,6 \\
\hline & $\gamma\left(\mathrm{kN} / \mathrm{m}^{3}\right)$ & \multicolumn{2}{|c|}{15,3} \\
\hline \multirow{3}{*}{ Solo Topo- Piau } & $\phi\left(^{\circ}\right)$ & 31,9 & 29,6 \\
\hline & $\mathrm{c}(\mathrm{kPa})$ & 396,6 & 95,5 \\
\hline & $\gamma\left(\mathrm{kN} / \mathrm{m}^{3}\right)$ & \multicolumn{2}{|c|}{16,13} \\
\hline \multirow{3}{*}{$\begin{array}{l}\text { Solo Topo- BR } \\
101\end{array}$} & $\phi\left(^{\circ}\right)$ & 48,3 & 26,4 \\
\hline & $\mathrm{c}(\mathrm{kPa})$ & 259,3 & 109,7 \\
\hline & $\gamma\left(\mathrm{kN} / \mathrm{m}^{3}\right)$ & \multicolumn{2}{|c|}{17,08} \\
\hline \multirow{3}{*}{$\begin{array}{l}\text { Solo- Base dos } \\
\text { Taludes }\end{array}$} & $\phi\left(^{\circ}\right)$ & 28,4 & 26,8 \\
\hline & $\mathrm{c}(\mathrm{kPa})$ & 384,1 & 45,4 \\
\hline & $\gamma\left(\mathrm{kN} / \mathrm{m}^{3}\right)$ & \multicolumn{2}{|c|}{15,33} \\
\hline \multirow{3}{*}{$\begin{array}{l}\text { Camada } \\
\text { cimentada }\end{array}$} & $\phi\left(^{\circ}\right)$ & 35 & 35 \\
\hline & $\mathrm{c}(\mathrm{kPa})$ & 1000 & 1000 \\
\hline & $\gamma\left(\mathrm{kN} / \mathrm{m}^{3}\right)$ & \multicolumn{2}{|c|}{20} \\
\hline
\end{tabular}

\subsubsection{Análise da estabilidade}

Nas análises adotou-se um perfil de falésia (Figura 4) comumente encontrada na região, caracterizado por ser um perfil que forma aproximadamente $90^{\circ} \mathrm{com}$ a superfície horizontal e não apresenta incisão em sua base. Essas falésias possuem altura máxima de 40 metros. Verifica-se eventualmente a presença de cobertura vegetal em seu topo.

Outro perfil analisado apresenta a camada cimentada na interface dos solos, presente em algumas falésias (perfil 2, figura 4).
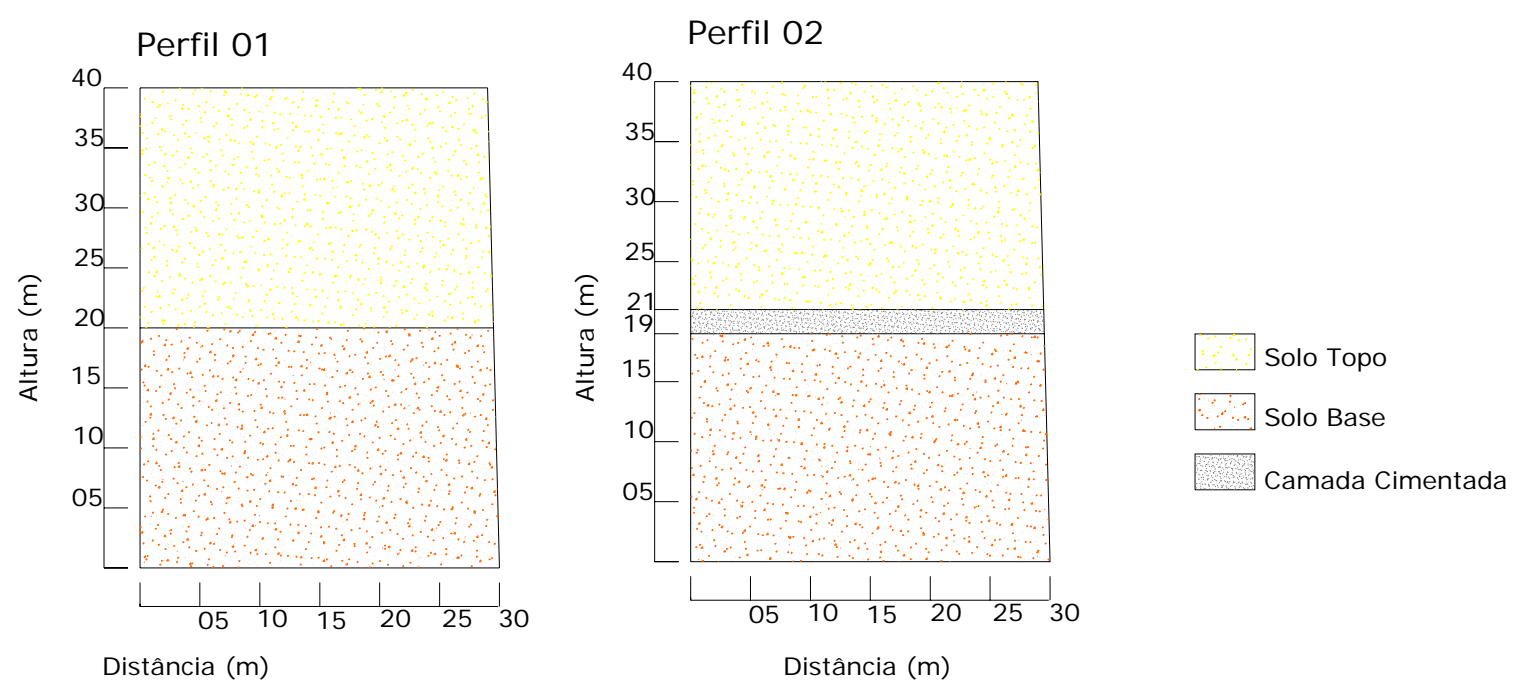

Figura 4. Perfil das falésias analisadas 
Através de levantamento junto aos poços de captação de água da região de Tibau do Sul - RN verificou-se que o nível do lençol freático permanece abaixo da base das falésias em qualquer época do ano, portanto não foi considerada a linha freática nas simulações de análise de estabilidade realizadas (SEVERO, 2005).

A análise foi feita permutando-se os Solos Topo com o Solo Base. Assim obtiveram-se três situações de falésias, cada uma composta por um dos Solos Topo e o Solo Base:

1. a primeira situação foi realizada com os parâmetros do Solo Base da falésia para estes servirem como o solo da base para as falésias das simulações, e com os parâmetros do Solo Topo encontrado na BR 101 (Solo Topo BR 101) para estes servirem como solo do topo para as falésias das simulações;

2. a segunda situação foi realizada com os parâmetros do Solo Base da falésia para estes servirem como base para as falésias das simulações, e os parâmetros do Solo Topo encontrado em Piau (Solo Topo Piau) para estes servirem como solo do topo para as falésias das simulações;

3. a terceira situação foi realizada utilizando-se os parâmetros do Solo Base das falésias para estes servirem como solo de base para as falésias das simulações, e os parâmetros do Solo Topo da falésia (Solo Topo Falésia) para estes servirem como solo do topo para as falésias das simulações.

Foram formulados sete casos para averiguar o comportamento dos taludes em diferentes situações. Cada caso apresentará simulações com as três situações de falésias acima citadas. Os casos aqui apresentados não encerram todas as possibilidades possíveis de ocorrência na natureza, mas são as que fornecem maior quantidade de dados para estudos. A tabela 2 informa os casos levados em consideração na pesquisa.

As simulações levaram em consideração as situações acima citadas, juntamente com o perfil das falésias adotado, os parâmetros de resistência dos solos e os casos considerados. Elas foram realizadas no programa GeoSlope, que utiliza os Métodos de Equilíbrio Limite, em especial os métodos de Fellenius, Bishop, Janbu e MorgensternPrice. As simulações foram realizadas com o método que apresentou o menor Fator de Segurança. Nos casos em que o Fator de Segurança apresentar-se abaixo de 1, são grandes as possibilidades de deslizamento de solo, e acima disso, a falésia apresenta uma certa estabilidade.

Foram realizadas vinte e uma simulações onde se visou mostrar os taludes em diferentes graus de saturação, analisando a influência da saturação e da camada cimentada na estabilização das falésias. Como resultado dessas análises obtiveram-se os menores Fatores de Segurança e as prováveis superfícies de escorregamento. 
Tabela 2 - Situações Consideradas na Análise da Estabilidade

\begin{tabular}{|c|c|c|c|c|}
\hline Caso & Estado dos Solos & Situação 1 & Situação 2 & Situação 3 \\
\hline 01 & Não Saturados & $\checkmark$ & $\checkmark$ & $\checkmark$ \\
\hline 02 & Não Saturados e Camada Cimentada & $\checkmark$ & $\checkmark$ & $\checkmark$ \\
\hline 03 & Topo Saturado e Base Não Saturada & $\checkmark$ & $\checkmark$ & $\checkmark$ \\
\hline 04 & $\begin{array}{l}\text { Topo Saturado, Base Não Saturada e Camada } \\
\text { Cimentada }\end{array}$ & $\checkmark$ & $\checkmark$ & $\checkmark$ \\
\hline 05 & Topo Saturado e Saturação Limite & $\checkmark$ & $\checkmark$ & $\checkmark$ \\
\hline 06 & Todos os Solos Saturados & $\checkmark$ & $\checkmark$ & $\checkmark$ \\
\hline 07 & $\begin{array}{l}\text { Todos os Solos Saturados e } \\
\text { Cimentada }\end{array}$ & $\checkmark$ & $\checkmark$ & $\checkmark$ \\
\hline
\end{tabular}

\section{RESULTADOS}

\subsection{Solos de topo e base na umidade natural}

Os solos de topo e base estando em umidade natural, mesmo sem a existência de camadas cimentadas, apresentam fatores de segurança elevados, o que garante a estabilidade das falésias nestas situações. Percebe-se que a superfície de deslizamento abrangeria todo o talude em todas as situações. As diferenças nos fatores de segurança se devem aos parâmetros de cada solo. O método Bishop foi o que apresentou os menores fatores de segurança dentre os métodos analisados.

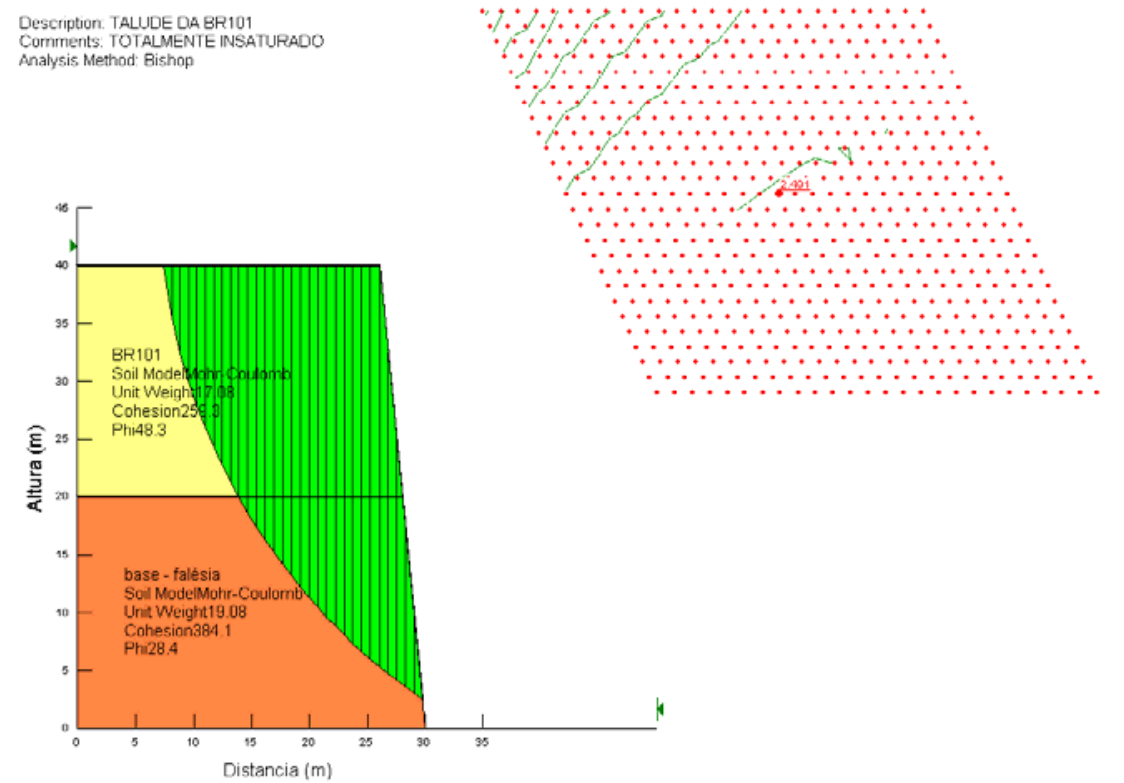

Figura 5 - Solo Topo da BR101 e Solo Base na umidade Natural. 
Description TALUDE EM PAU Comments SOLOS TOTALMENTE INSATURADOS

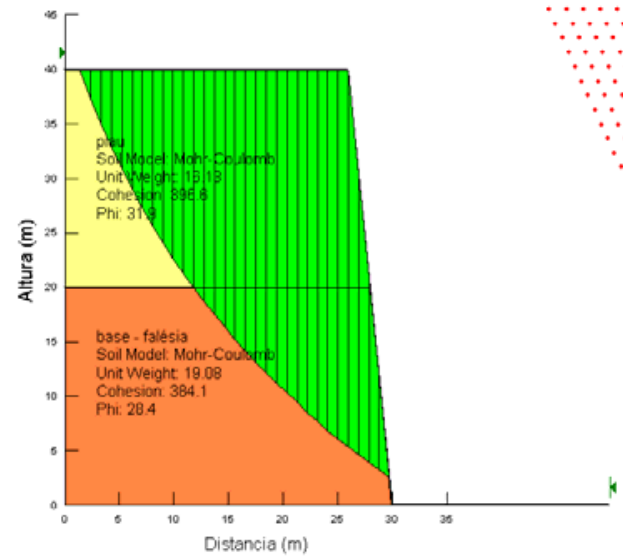

Figura 6 - Solo Topo Piau e Solo Base na umidade Natural

Description TOPO DA FALÉSIA

Comments: SOLO TOTALMENTE INSATURAD

Analysis Mothod: Bishop
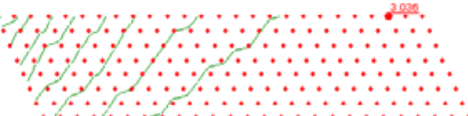
. 


\subsection{Solos de topo e base na umidade natural com uma camada cimentada}

Para os solos nas umidades naturais, a camada cimentada ofereceu um acréscimo pequeno ao fator de segurança. Observou-se também que a superfície potencial de deslizamento praticamente não se alterou. Mais uma vez, o método Bishop foi o que apresentou os menores fatores de segurança.

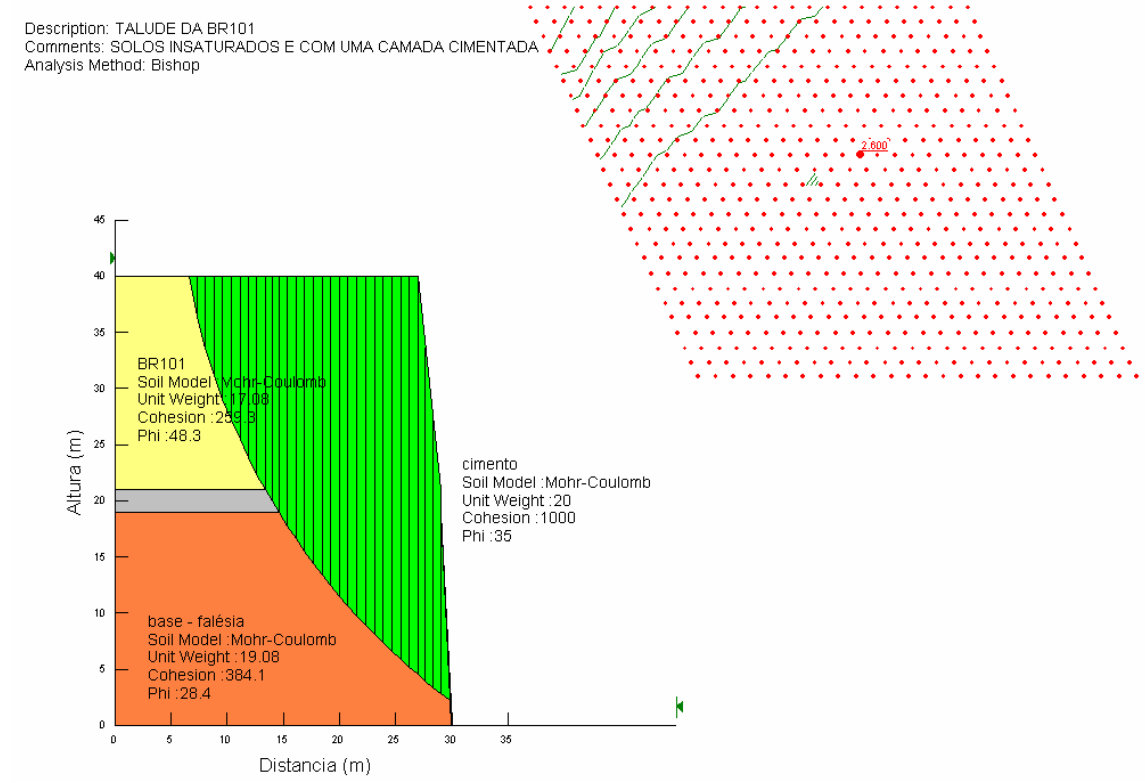

Figura 8 - Talude da BR101 na umidade natural e com camada cimentada

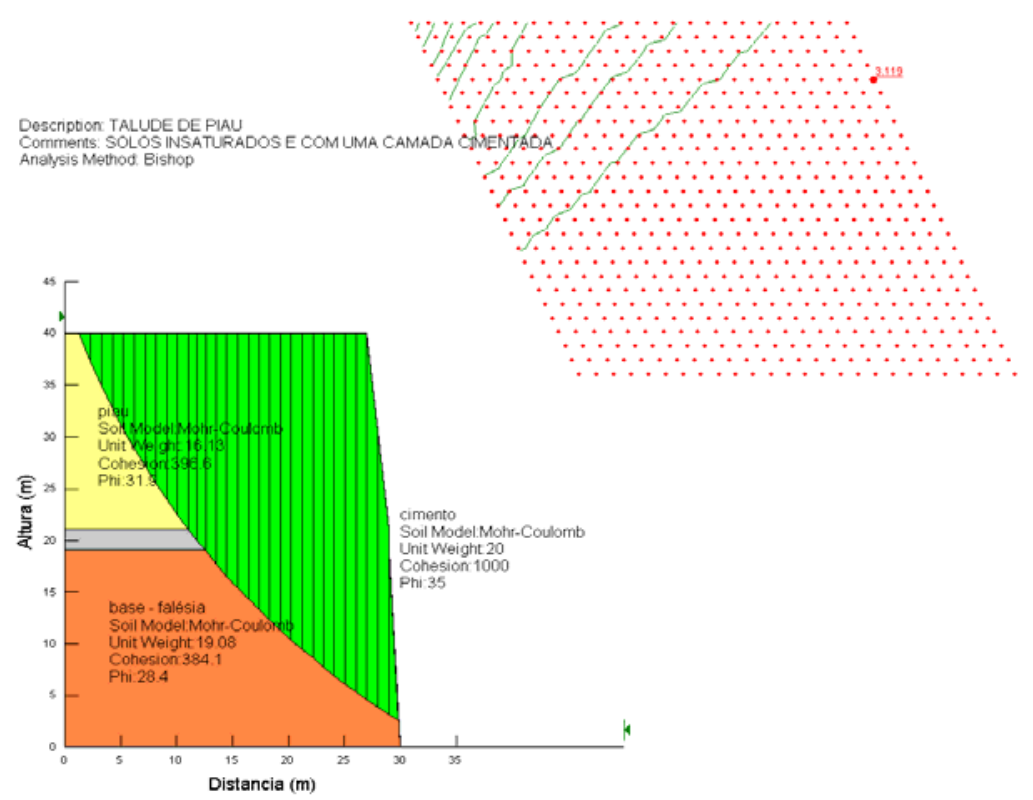

Figura 9 - Talude de Piau na umidade natural e com camada cimentada 

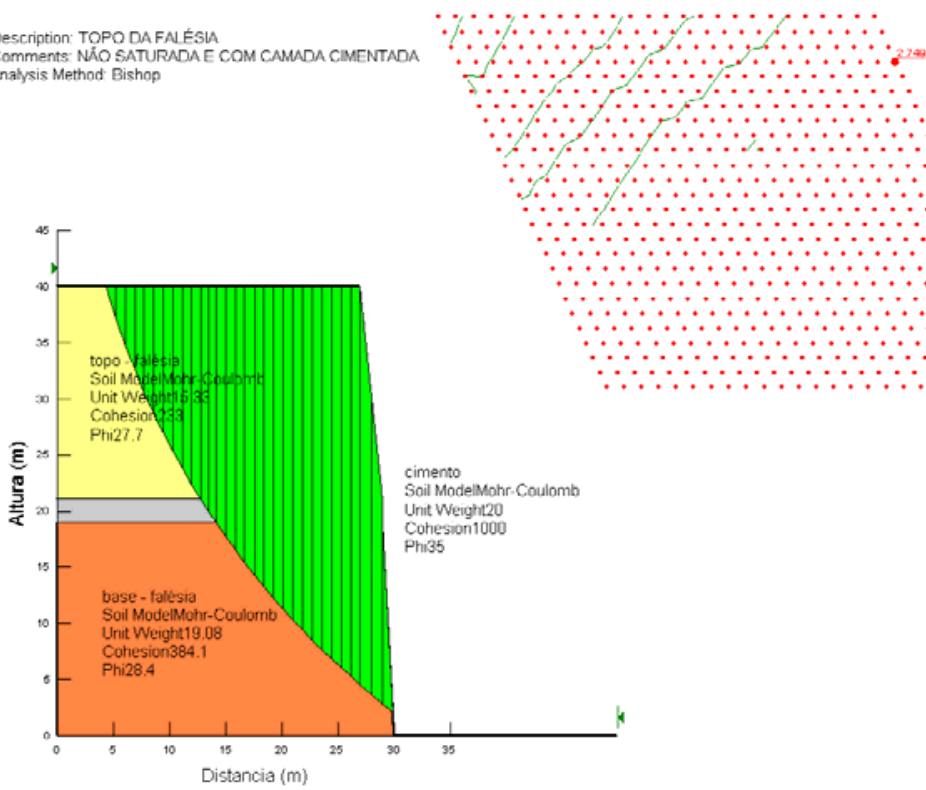

Figura 10 - Falésia com solos na umidade natural e com camada cimentada

\begin{tabular}{|l|c|l|c|c|}
\hline \multirow{2}{*}{ Solo } & \multicolumn{4}{|c|}{ Método } \\
\cline { 2 - 5 } & Ordinary & Bishop & Janbu & M-P \\
\hline Piau & 3.292 & 3.200* & 4.437 & 10.291 \\
\hline Falésia & 2.885 & $\mathbf{2 . 7 9 3} *$ & 3.112 & 5.259 \\
\hline BR-101 & 2.836 & $\mathbf{2 . 6 0 2} *$ & 2.965 & 5.844 \\
\hline
\end{tabular}

\subsection{Solo de topo saturado e base não saturada}

Quando o Solo Topo está saturado e o Solo Base não, situação comum na área estudada, haja vista a baixa permeabilidade dos solos e a ausência de lençol freático nas falésias, se observa uma redução significativa dos FS. Essa redução da ordem de $50 \%$ em relação à situação de umidade natural para as três situações analisadas. Ainda assim não suficiente para atingir a instabilização dos taludes. Apenas o talude com o Solo Topo da falésia (Figura 13) é que se encontraria perto de uma provável ruptura, pois seu FS está próximo de 1.

Nota-se que a provável ruptura restringir-se-ia apenas aos solos saturados, os Solos Topo, e avançariam cerca de dez metros, na horizontal, sobre o talude. 

Description: TALUDE DABR101
Comments: TOPO SATURADO Analysis Method: Bishop.

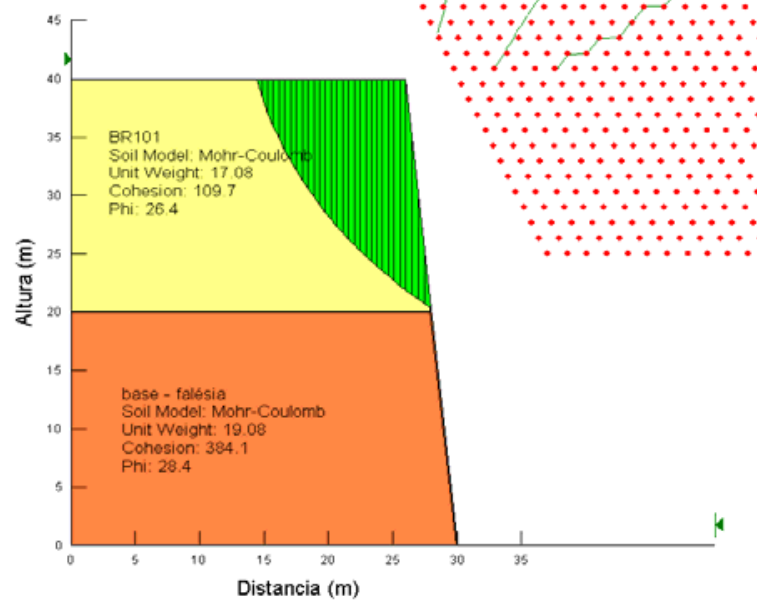

Figura 11 - Talude da BR101 com o Solo Topo saturado

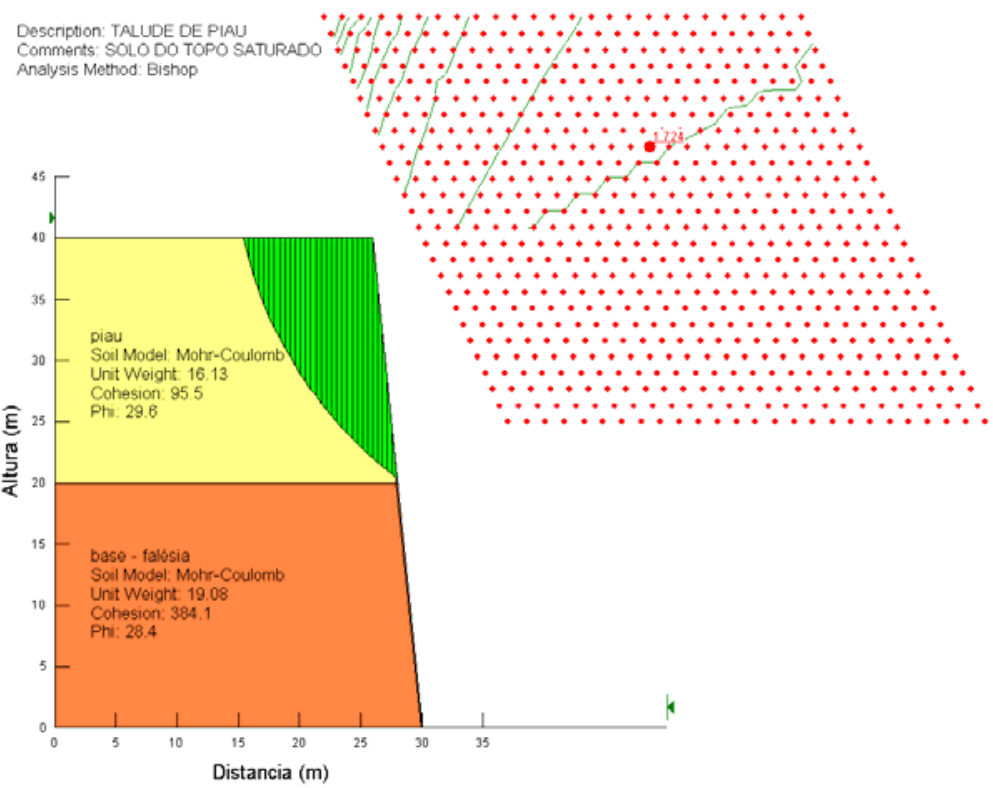

Figura 12 - Talude de Piau com o Solo Topo saturado 


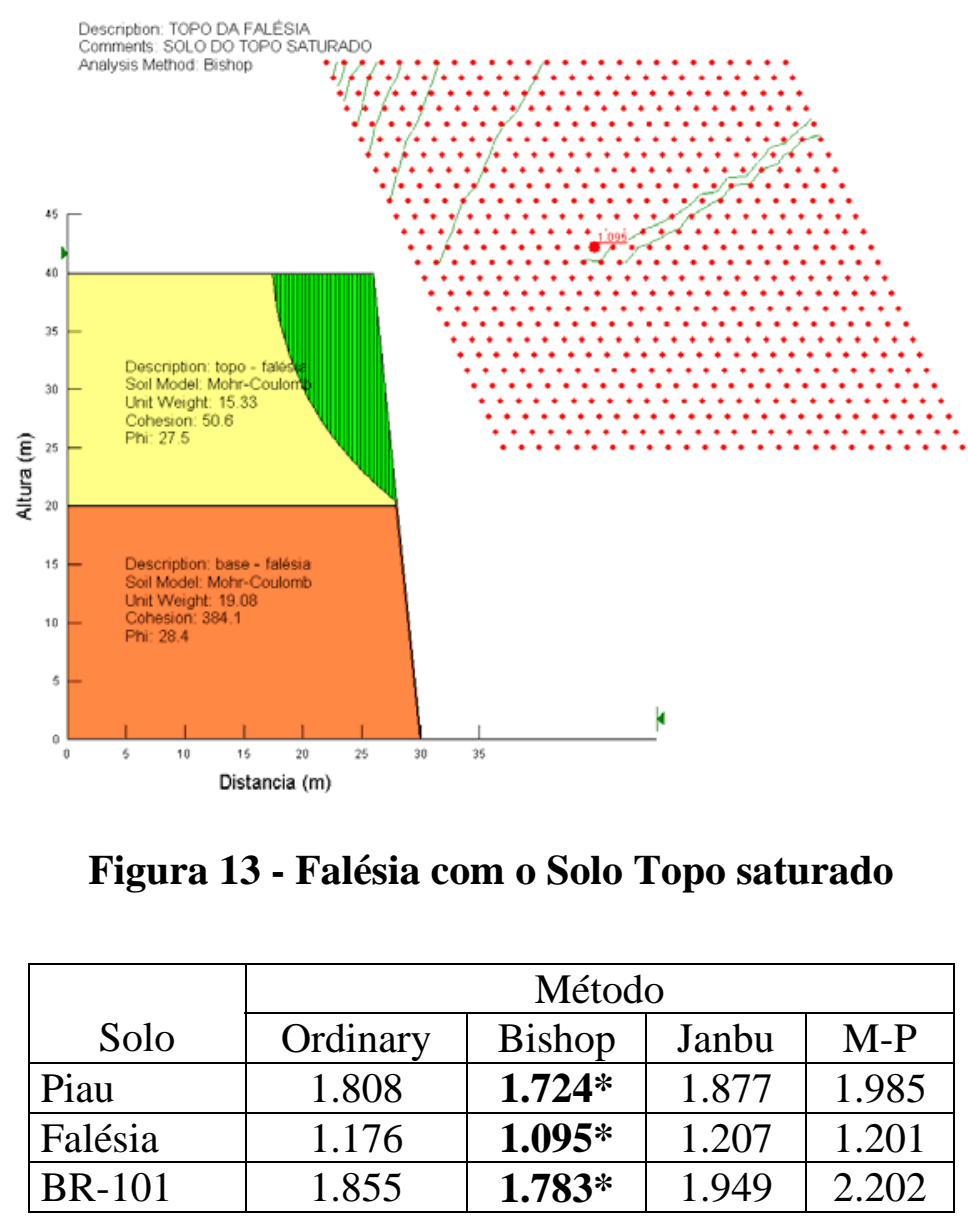

\subsection{Solos dos topos saturados e bases não saturadas incluindo uma camada cimentada}

Também nesse caso, a presença de uma camada cimentada não altera significativamente os valores dos fatores de segurança, não contribuindo, nesse caso para a estabilização dos taludes.

Como no caso 3, a provável superfície de ruptura restringir-se-ia apenas ao solo saturado, o Solo Topo.

Nota-se que, mais uma vez, o método Bishop foi o que apresentou os menores fatores de segurança. 


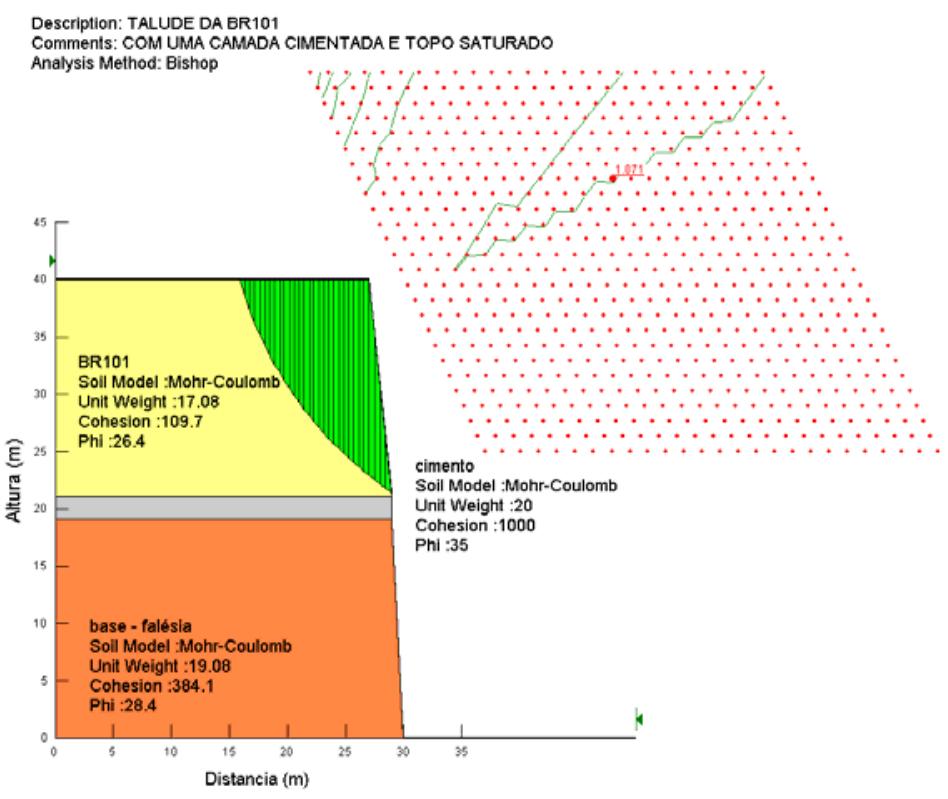

Figura 14 - Talude da BR101 com o Solo Topo saturado e com camada cimentada

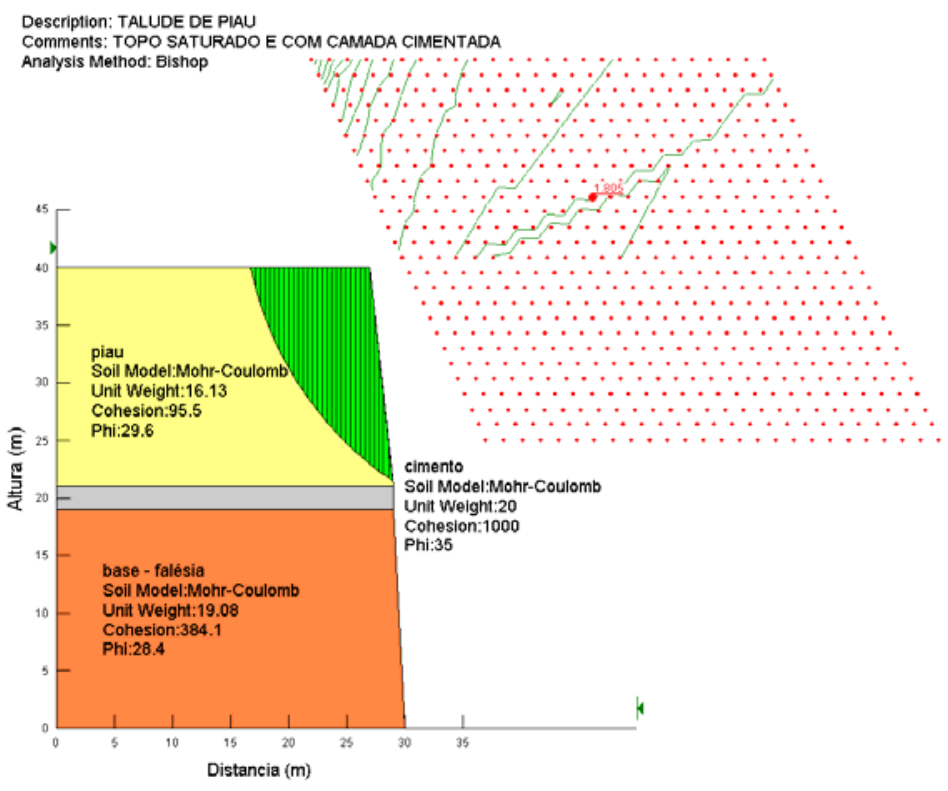

Figura 15 - Talude de Piau com Solo Topo saturado e com camada cimentada 


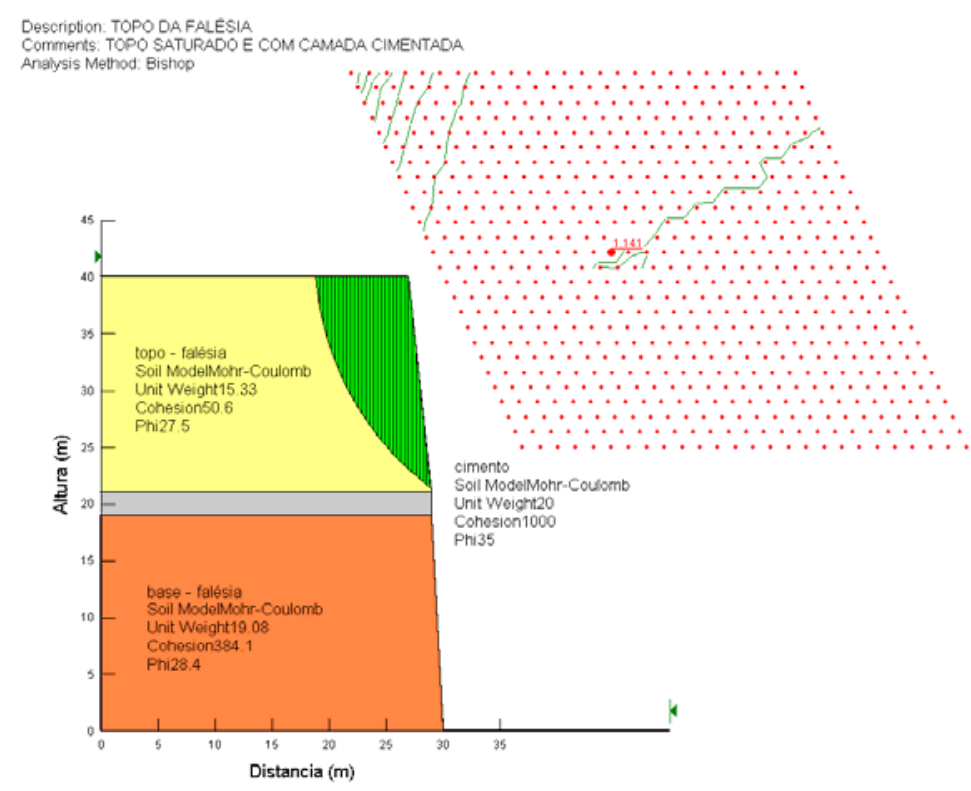

Figura 16. Falésia com Solo Topo saturado e com camada cimentada

\begin{tabular}{|l|c|l|c|c|}
\hline \multirow{2}{*}{\multicolumn{1}{|c|}{ Solo }} & \multicolumn{4}{|c|}{ Método } \\
\cline { 2 - 5 } & Ordinary & Bishop & Janbu & M-P \\
\hline Piau & 1.890 & $\mathbf{1 . 8 0 5}^{*}$ & 1.969 & 2.318 \\
\hline Falésia & 1.225 & $\mathbf{1 . 1 4 1}^{*}$ & 1.258 & 1.245 \\
\hline BR-101 & 1.942 & $\mathbf{1 . 8 7 1}^{*}$ & 2.038 & 2.448 \\
\hline
\end{tabular}

\subsection{Situação de saturação limite}

Foram feitas diversas simulações em cada situação avançando-se a frente de saturação para atingir-se a instabilização, ou seja, até obter um FS menor que 1,0.

Na primeira situação (Figura 17) - Solo Topo da BR 101 - a instabilização ocorre com 12 metros de saturação da camada da base, de cima para baixo, atingindo-se, como informa a tabela, um FS de 0,972 no método Bishop.

Na segunda situação (Figura 18), a instabilização ocorre com uma saturação na camada da base de 11 metros, de cima para baixo, atingindo-se um FS igual a 0,974 no método de Bishop.

Na terceira situação (Figura 19), a instabilização da falésia ocorreria com uma saturação de 3 metros da camada da base, de cima para baixo, obtendo-se um fator de segurança de 0,999 pelo método Bishop.

As prováveis superfícies de deslizamento abrangeriam apenas os solos saturados, e teriam uma distância horizontal, no topo, de 10 metros em média. 


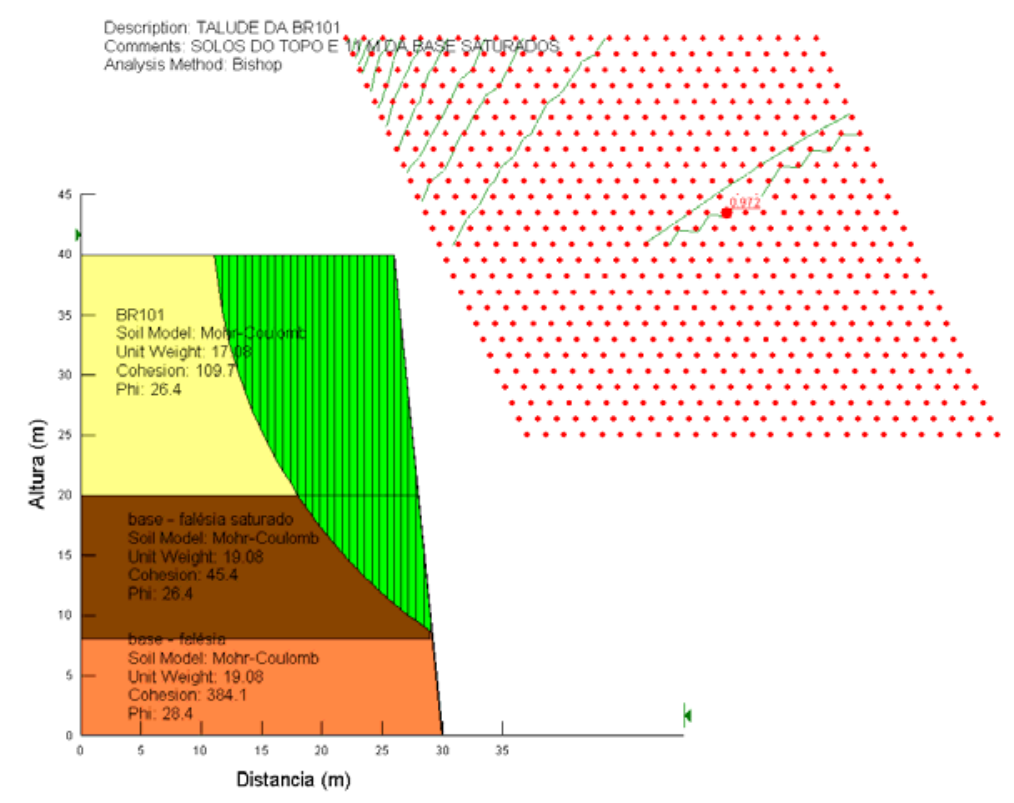

Figura 17 - Talude da BR 101 com o solo do topo saturado e 12 metros de saturação no Solo Base

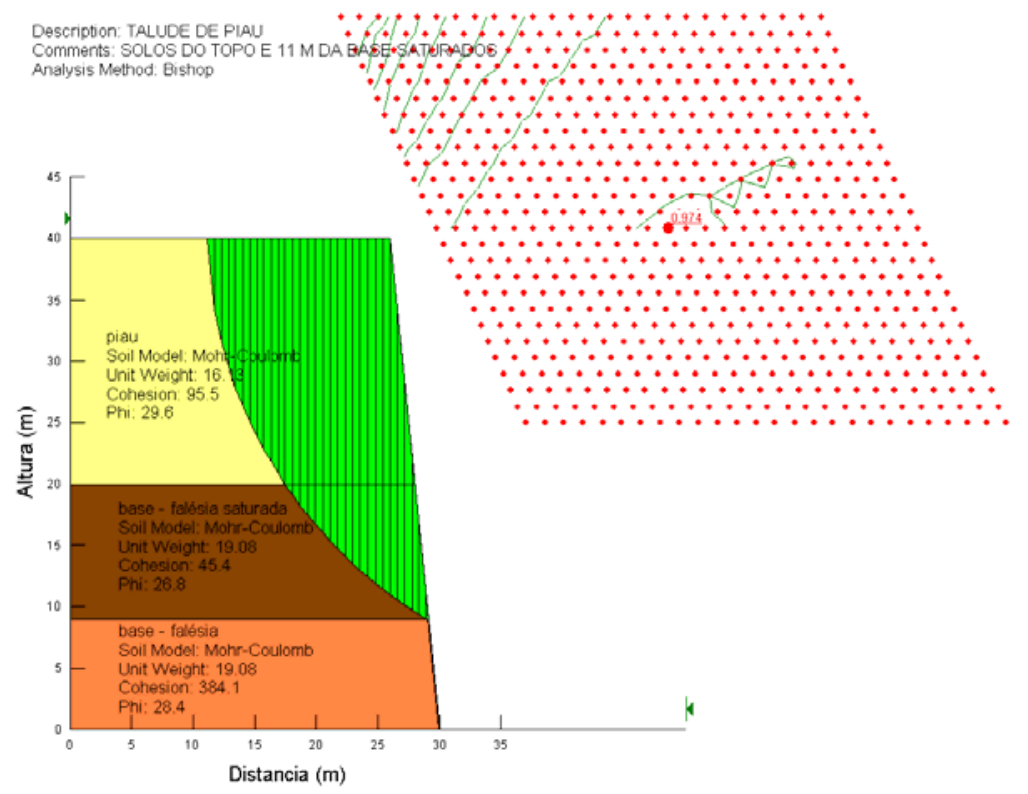

Figura 18 - Talude de Piau com o solo do topo saturado e com 11 metros do Solo Base em saturação 


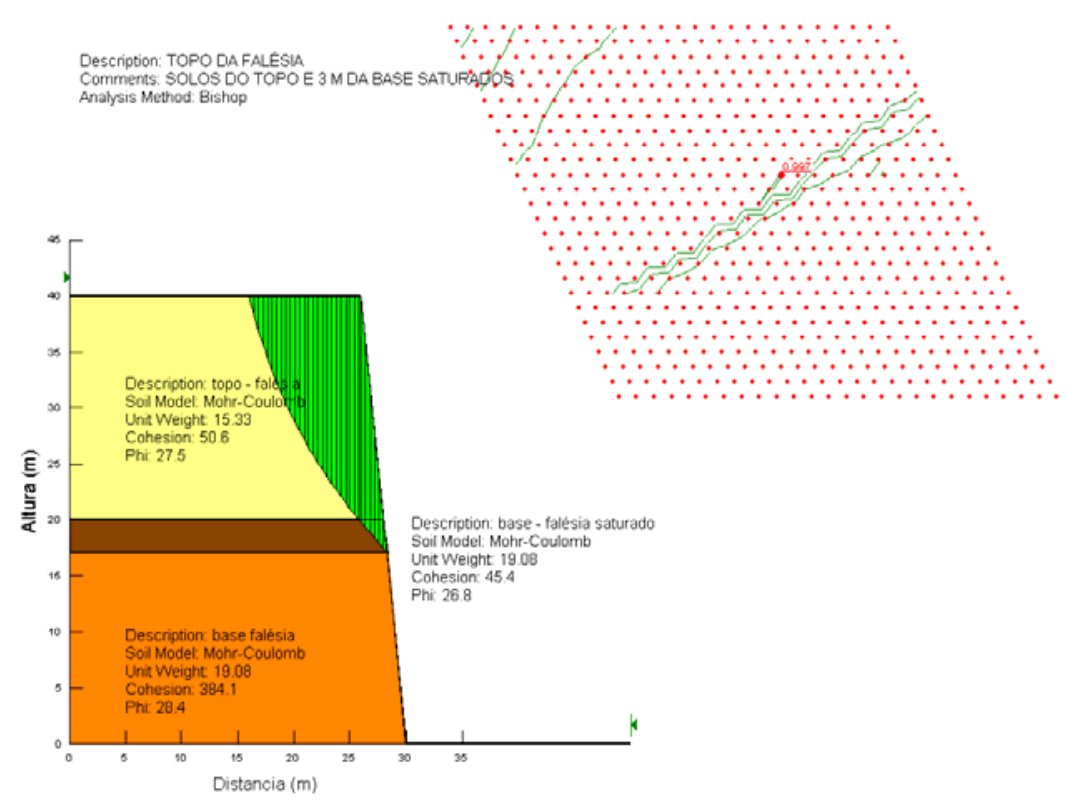

Figura 19 - Falésia com o Solo Topo saturado e 3 metros do Solo Base em saturação

\begin{tabular}{|l|c|l|c|c|}
\hline \multirow{2}{*}{ Solo } & \multicolumn{4}{|c|}{ Método } \\
\cline { 2 - 5 } & Ordinary & Bishop & Janbu & M-P \\
\hline Piau & 1.112 & $\mathbf{0 . 9 7 4}$ & 1.173 & 1.297 \\
\hline Falésia & 1.055 & $\mathbf{0 . 9 9 9}$ & 1.121 & 1.124 \\
\hline BR-101 & 1.096 & $\mathbf{0 . 9 7 2} *$ & 1.179 & 1.409 \\
\hline
\end{tabular}

\subsection{Solos dos topos e das bases saturados}

Com os solos dos taludes completamente saturados percebe-se a total instabilização destes. $\mathrm{O}$ fator de segurança fica em torno de 0,7 nas três situações, ou seja, a ruptura ocorre muito antes da saturação completa. A saturação dos solos diminuiu os fatores de segurança em torno de $75 \%$ com relação aos solos nas umidades naturais. A ruptura abrangeria quase completamente o talude no sentido vertical, e avançaria cerca de quinze metros sobre a superfície do talude. 
Description: TALUDE DA BR101

Comments: TODOS OS SOLOS SATURADOS

Analysis Method Bishop

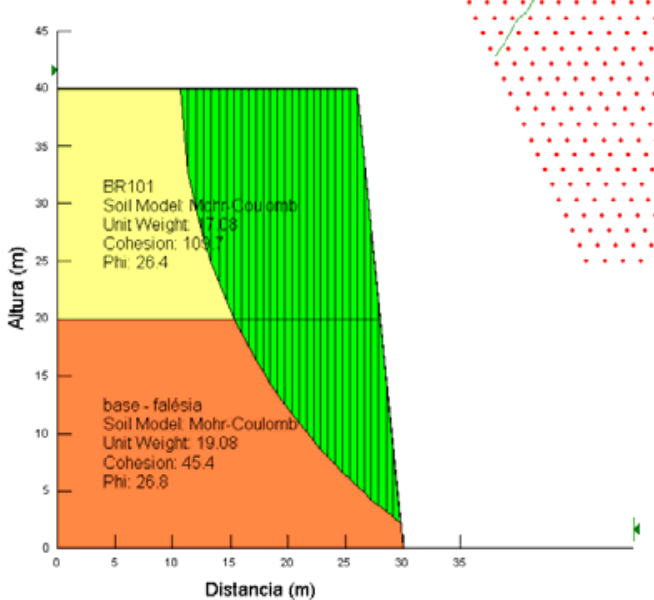

Figura 20 - Talude da BR101 com todos os solos saturados

Description: TALUDE DE PIAU

Comments TODOS OS SOLOS SATURADOS

Analysis Method. Bishop

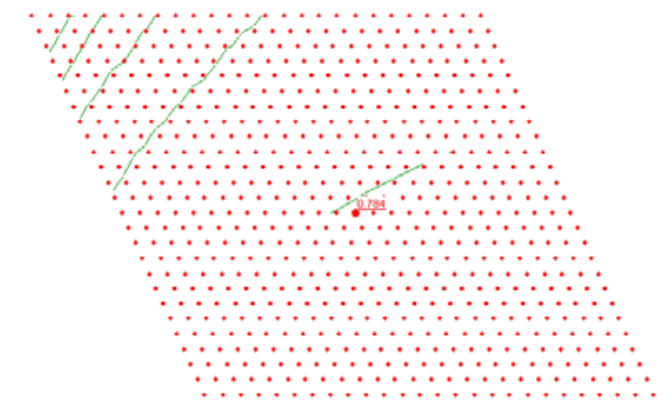




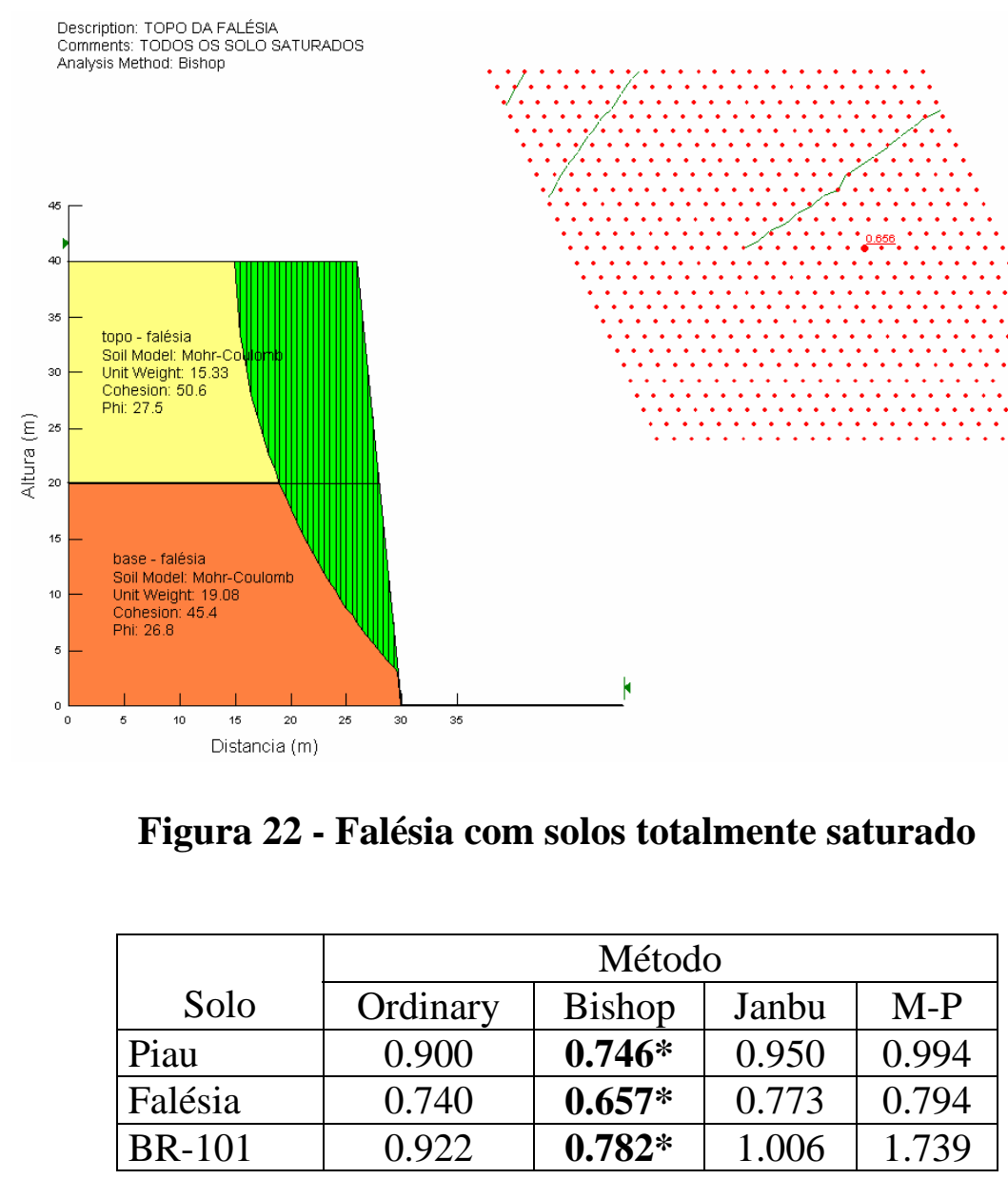

\subsection{Solos dos topos e bases saturados incluindo uma camada cimentada}

Com a presença da camada cimentada aumentaram-se consideravelmente os fatores de segurança para os três taludes, porém para a terceira situação (Figura 25) essa camada não seria suficiente para conter a possível ruptura.

Nos outros casos, mesmo os solos encontrando-se completamente saturados, a camada cimentada fornece resistência considerável à ruptura da falésia.

Percebe-se que a camada cimentada não restringe a superfície de deslizamento à parte do topo da falésia. Assim, na ruptura, também essa camada de solo seria inclusa na ruptura. 
Description: TALUDE DA BR101

SOLOS SATURADOS E COM CAMADA CIMENTADA Analysis Method:Bishop

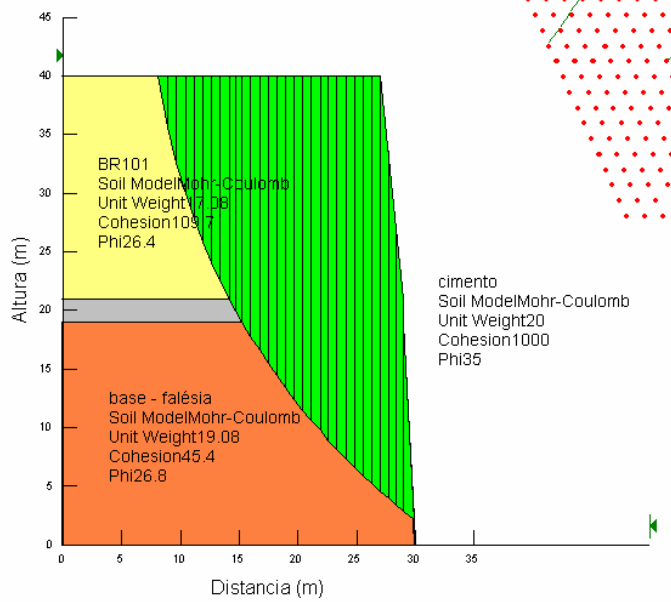

Figura 23 - Talude da BR 101 com todos os solos saturados e com camada cimentada

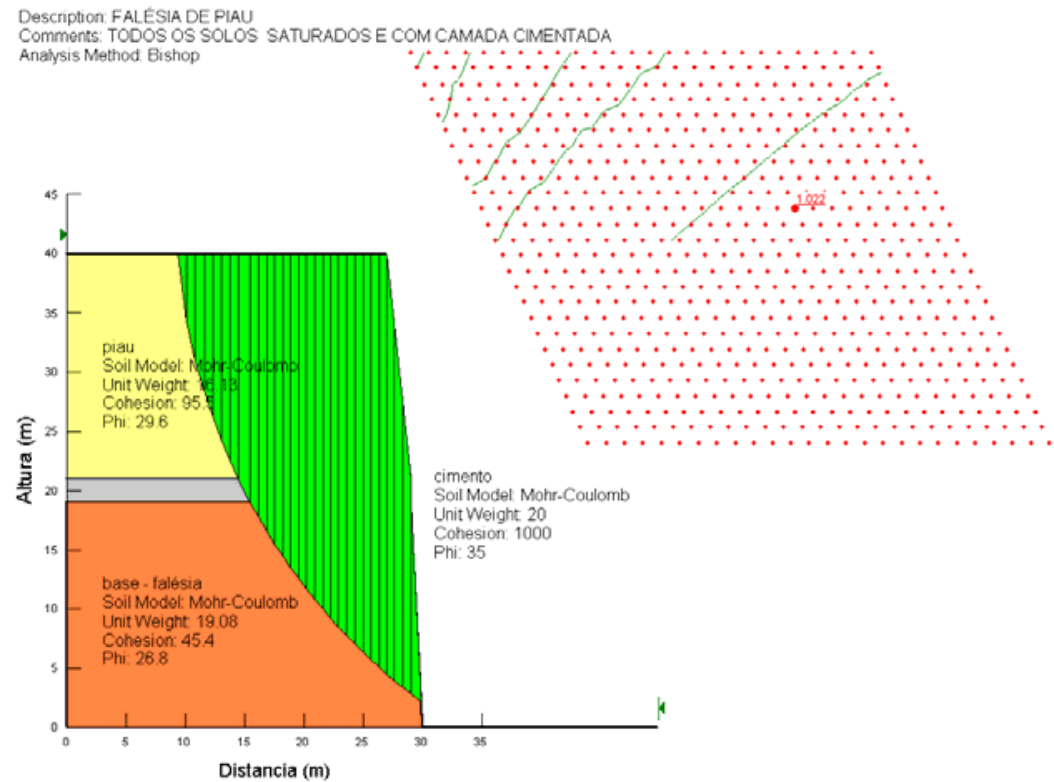

Figura 24 - Talude de Piau com todos os solos saturados e com camada cimentada 


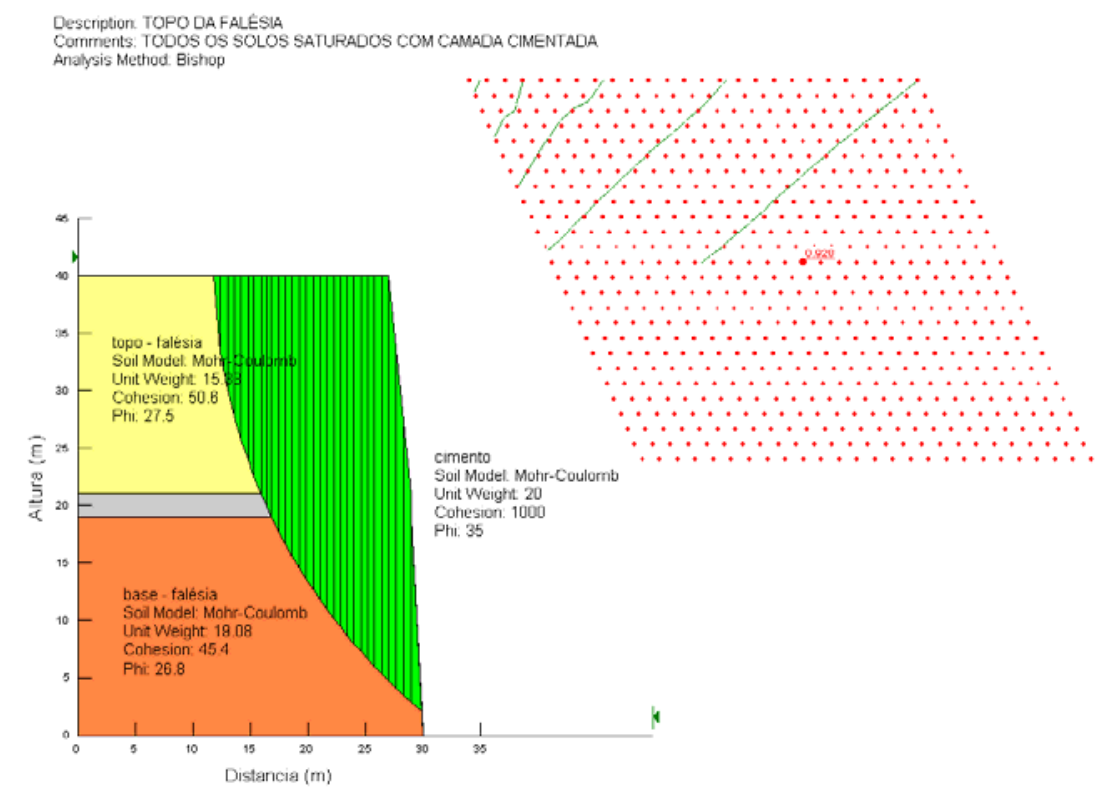

Figura 25 - Falésia com todos os solos saturados e com camada cimentada

\begin{tabular}{|l|c|l|l|c|}
\hline \multirow{2}{*}{\multicolumn{1}{|c|}{ Solo }} & \multicolumn{4}{|c|}{ Método } \\
\cline { 2 - 5 } & Ordinary & Bishop & Janbu & M-P \\
\hline Piau & 1.216 & $\mathbf{1 . 0 1 9}^{*}$ & 1.269 & 1.692 \\
\hline Falésia & 1.097 & $\mathbf{0 . 9 2 8}^{*}$ & 1.107 & 1.143 \\
\hline BR-101 & 1.223 & $\mathbf{1 . 0 4 6}^{*}$ & 1.295 & 2.094 \\
\hline
\end{tabular}

\section{CONCLUSÕES}

A ferramenta utilizada para o cálculo da estabilidade dos taludes foi o software SLOPE/W da Geo-Slope, versão estudante com o qual foram feitas simulações e obtido os respectivos fatores de segurança e prováveis superfícies de deslizamento. As simulações realizadas pelo método de Bishop apresentaram os menores fatores de segurança em todas as situações.

A ausência de vegetação, a ocorrência de incisões basais e fendas de tração e o aumento da umidade dos solos deixa as falésias vulneráveis à ocorrência de movimentos de massa.

A estabilidade das falésias foi reduzida à medida que foi incrementado o grau de saturação dos solos que compõem as mesmas. Na ocorrência da instabilidade observou-se que o movimento de massa predominante foram os deslizamentos de forma circular e com grande movimentação de terra.

Com os solos na umidade natural há uma grande estabilidade em todas as situações. A presença de uma camada cimentada na interface das camadas de solo contribui pouco para a estabilidade das falésias em todas as situações, exceto no caso dos solos completamente saturados, onde essa camada aumenta o Fator de Segurança a ponto de não 
haver ruptura nas simulações realizadas com o Solo Topo presente na BR 101 e com o Solo Topo presente em Piau.

O equilíbrio limite das falésias ocorre com todo o Solo Topo está completamente saturado e quando ocorre a saturação de mais 12 metros do Solo Base, na simulação onde está presente o Solo Topo da BR 101. Com todo o Solo Topo saturado e mais 11 metros da base na simulação onde está presente o Solo Topo de Piau. E na simulação onde está presente o Solo Topo da Falésia, a ruptura ocorreria com todo o Solo Topo encontrando-se saturado e mais 3 metros de saturação do Solo Base.

\section{REFERÊNCIAS BIBLIOGRÁFICAS}

CAPUTO, H P. Mecânica dos Solo e suas Aplicações: Mecânica das Rochas, Fundações, Obras de Terra. v.2. LTC: São Paulo,2003.

GUIDICINI, G.; NIEBLE, C. M. Estabilidade de Taludes Naturais e de Escavação. ed. Edgard Blücher: São Paulo, 1984.

ORTIGÃO, J. A. R. Introdução à Mecânica dos Solos dos Estados Críticos. Rio de Janeiro: Livros Técnicos e Científicos, 1993.

SANTOS Jr. e NÓBREGA. Relatório Técnico Sobre Instabilização de Encostas em Pipa-RN. Circulação Interna. 21p. 2000.

SILVA, W. de S. Estudo da Dinâmica Superficial e Geotécnico das Falésias do Município de Tibau do Sul - Litoral Oriental do RN. 2003. Dissertação (Mestrado em Engenharia Sanitária) - UFRN, Natal.

SERVERO, R N F. Análise da Estabilidade das Falésias entre Tibau do Sul e Pipa RN. 2005. Dissertação (mestrado em Engenharia Sanitária) - UFRN, Natal.

VARGAS, M. Introdução à Mecânica dos Solos. São Paulo: MC Graw-Hill do Brasil: Universidade de São Paulo, 1978. 